\title{
Impact Assessment of COVID-19 on Sugarcane Growers and Sugar Industry in Karnataka
}

\author{
Girish A Chavadappanavar \\ Department of Geography, KLE’S Lingaraj College, Belagavi, Karnataka, India
}

\begin{abstract}
The Karnataka sugar industry, a significant player in the national economy, has faced many challenges in the course of its journey. The threat posed by the growing pandemic novel corona virus (COVID - 19), has been the most recent one and it is impacting sugar industry stakeholders and its integrated industries, not only in Karnataka, but all over the India. The entire value chain of the Karnataka sugar industry, viz., sugarcane, sugar, molasses, ethanol and their subsequent marketing and export, has been adversely affected from the spillover impacts. The major impacts of COVID - 19 on Karnataka sugar industry are discussed.
\end{abstract}

\section{Introduction}

Karnataka Sugar Industry ranks $3^{\text {rd }}$ in terms of its contribution of sugar in the total sugar production in the country. The Sugar Industry in Karnataka is able to manufacture sugar in such huge quantities due to the fact that sugarcane is abundantly available in the state. In fact, Karnataka stands 4 th in the country in the cultivation of sugarcane.

The Sugar Industry in Karnataka has around 41 sugar factories which are distributed all over the state. The various locations of the sugar factories of Karnataka Sugar Industry are Konnur, Varuna, Koppa, Madapura, Dandeli, Jambagi, Hosur, Margur, Yelgur, Siddapur, and Arsanghatta. The major benefits of Karnataka Sugar Industry are that it has generated many facilities in the state such as communication, employment, and transport. It has also benefited the state by helping in the development of the rural areas of the state by mobilizing the various resources of the villages. The major sugar factories of Karnataka Sugar Industry are:

- Bannari Amman Sugar Ltd. with the sugarcane crushing capacity of 5000 TCD

- Davangere Sugar Company Ltd. with the sugarcane crushing capacity of 2500 TCD

- Sri Chamundeswari Sugars Ltd. with the sugarcane crushing capacity of 4000 TCD

- Godavari Sugar Mills Ltd. with the sugarcane crushing capacity of 7500 TCD

- Mysore Sugar Company Ltd. with the sugarcane crushing capacity of 5000 TCD

- Athani Farmers Sugar Factory Ltd. with the sugarcane crushing capacity of 2500 TCD

The Sugar Industry in Karnataka can be divided into 2 groups that are the unorganized sector which comprises of the producers of the traditional sweeteners such as gur and khandsari and the organized sector which consists of the sugar mills. The manufacture of khandsari and gur is considered to be rural industry and are produced in huge quantities. The gur and khandsari are consumed mostly by the rural people as sources of nutrition and also as sweeteners. The total sugar production of Karnataka Sugar
Industry came to 17.98 lakh tons in 2002 2003, in 2003 2004 the figure came to 11.57 lakh tons, and in 20042005 the figure stood at 13 lakh tons.

The Sugar Industry in Karnataka contributes around ' 36 crore per year to the state exchequer in central excise duty. It also contributes more than ' 900 crore in the form of turnover tax and sales tax to the state exchequer. The state government in an attempt to boost Karnataka Sugar Industry has set up the Karnataka Sugar Institute (KSI) which has emerged as a center for education and training for sugar technology. The Karnataka Sugar Institute also provides important support to the Sugar Industry in Karnataka by doing $R \& D$ in the various aspects of sugarcane processing and production.

Karnataka Sugar Industry has contributed a great deal to India's total level of sugar production and thus has helped the country to meet its demand for sugar. The Karnataka state government must make more efforts in order to boost the sugar industry in Karnataka.

\section{Seasonality of Sugarcane in Karnataka}

Karnataka Sugarcane planting is done in December February for the 12 - month crop which is called Eksali, in October - November for the 15 to 16 month crop which is called Preseasonal, and in July - August for the 18 - month crop, which is called Adsali. General performance factors: Mean cane yield: . . . Recommended region for release: An early va. . . Botanical description: (a). Cane type: Medium t. .

\section{Emerging Challenges in Sugar Industry due to COVID - 19}

With varying sowing and harvesting period of sugarcane, the countrywide lockdown Announced on 25th March to combat the spread of COVID - 19 pandemic coincided with Planting, production and harvesting stages of sugarcane across different production hubs in the country. As per the estimates of experts in industry more than $80 \%$ of the harvesting was completed before the lockdown and rest was done during the time of lockdown.

The lockdown measures announced in India had a significant impact on the sugarcane Industry. While farmers 
have been affected due to lack of availability and access to labour and agriculture inputs, Sugar mills countered issues due to reduced demand of sugar in both domestic and international markets along with shortage of labour and other materials (like sulphur, gunny bags) for carrying out crushing and distribution operations.

\section{Impact on sowing and production stages}

Excessive rains across most paths of the state during this year's south West monsoon are now set to retreat. Meanwhile, the pandemic has not affected agricultural activity if the sowing status is any indication, as per the reports of the Karnataka state Natural Disaster Monitoring Center (KSNDMC)

The sowing target for kharif was 73 lakh hectares against which the actual coverage as of September 30, 2020, was 77.5 lakh hectares. This is more than the actual area covered during the corresponding periods last year when 68.84 hectares was brought under sowing, KSNDMC's Statistics reveal brought under sowing, KSNDMC's statistics reveal.

The converge of food grains was spread over 53.75 lakh hectares oil seeds accounted for 10.05 lakh hectares and cash crop was spared over 13.69 lakh hectares while 6.72 lakh hectares was brought under ragi, Maize accounted for 14.14 lakh hectares and jowar covered an area of 0.73lakh hectares in the state. Besides, 19.58 lakh hectares was brought under pulses. South interior Karnataka composing 11 districts brought in 20.44 lakh hectares of land under sowing against the target of 22.74 lakh hectares and the area met $90 \%$ of the target. North interior Karnataka composing 12 districts brought 50.69 lakh hectares under sowing against a target of 46.81 lakh hectares and achieved $108 \%$ of the actual target, as per KSNDMC statistics.

Meanwhile, continuing rains in parts of south interior Karnataka attributed to the low pressure area over the Bay of Bengal are expected to persist for a few days but will not have any negative impact on standing crops.

\section{Impact of COVID - 19 on Harvesting and crushing of sugarcane}

The impact of lockdown due to COVID - 19 has led to challenges in harvesting and milling in the largest producing District, Belagavi. Since sugarcane is predominantly harvested manually, labour requirement during harvesting period peaks. The last phase of harvesting in Belagavi was the one which got most affected. The districts in south and North West had almost completed their harvesting and therefore were less affected. The process of milling though was affected both on account of less quantum of the crop harvested and shortage of adequate labour to carry out milling functions. The lower availability of sugarcane is forcing the mills to operate at less than $100 \%$ capacity. Often during the harvest season, this is a very small window for us to operate. The sugarcane industry is estimating a loss of about 26, 444 tons due to problems related to harvesting during the lockdown at a higher price. As per the extension advisors and experts of sugarcane farming, non - application of some important crop protection materials and fertilizers on time may potentially damage the crop and reduce the productivity. Some of the manual operations like weeding and other intercultural operations were also due during this time, these operations were affected due to shortage in availability of labor especially in states like Maharashtra Kerala.

\section{Impact on demand of sugar in domestic and export market}

The most visible impact of the COVID - 19 crisis is on demand of sugar. Institutional consumption in Karnataka normally constitutes $65 \%$ of total domestic sugar sales, which is estimated at 26.5 million tons annually. The pandemic could impact the overall domestic sugar consumption by $5-8 \%$ ( $1-1.5$ million tons). The months of April, May and June are important months for marriage and other social events which are either postponed or cancelled. These events are high consumption points for sugar in form of Karnataka sweets and confectionaries. The demand from regular sweet shops and bakeries has also dried up. It is said that last two years had been bumper crop for sugar and sugar mills have a huge inventory from the past years. The season for year 2019 - 20 started with a balance of 14.58 million tons of sugar with sugar mills in October 2019 and by clubbing the estimated production of 26.5 million tons in the current season (2019 - 20), the total availability of sugar is estimated to be around 40.58 million tons. Against the availability, the consumption is estimated to be around 29 million tons including exports. Karnataka is likely to end with closing Stock of over 11.58 million tons in September 2020, which will be higher than than the earlier Estimate of 10 million tons.

\section{Implications on Sugar mills}

Farmers, though unhappy with the prices, had decided to sell the produce to factories; fearing delays would lead to losses. However, sugar factories are offering just Rs 2, 000 a tonne; they want the state government to pay the remaining Rs 500 a tonne. Of the 65 sugar factories in Karnataka, 58 are functional. While the cooperative sector has 22 factories, two are run by the government and 34 are privately owned. Of the private factories, 33 are owned/managed by politicians.

Belgaum district stands first in sugarcane production in Karnataka accounting for $35 \%$ of the state's total production. With 21 sugar factories, the district produces 1.30 crore tonnes of sugarcane every year, while the total production in the state standsat 3.5 crore tonnes. Bagalkot has nine factories while Bidar has four, Bijapur, Gulbarga and Davanagere three each. Last year, the farmers in Bagalkot district had produced 1.3 crore tonnes of sugarcane in four lakh acres of land. But this year the production has come down to 1.10 crore tonnes. The nine factories in the district together have the capacity of crushing 70, 000 tonnes per day. Only two factories - Ranna Sugars in Mudhol and Sameerwadi sugar factory in Sameerwadi of Bagalkot district have started crushing the canes. Sameerwadi Sugars after crushing 96, 000 tonnes had stopped crushing following an agitation staged by farmers. Sameerwadi Sugars has already started paying the farmers at the rate of Rs 2, 000 per tonne. Last year 3.20 crore tonne of sugarcane yield was recorded in the State. However this year, it has reduced to 2.88 crore tonnes. There has been a decline in the yield of sugarcane not only in Karnataka but also in Andhra 
Pradesh, Maharastra and Tamilnadu. President of State Sugarcane Growers' Association Kurabur Shantakumar said the farmers were not happy with the price fixed by the government but were ready to sell the standing crop because any delay would cause loss to the farmers as well as to the factories. If cane is not harvested in time, than recover level comes down.

He urged the factory managements to start crushing immediately and warned that the factories or the state government will have to make good any loss suffered by the farmers due to delay in crushing. He hoped that the factories in Belgaum district will commence crushing in a couple of days. Karnataka has 25 lakh sugarcane growers and the government earns Rs 6 crore every year by way of tax from this sector, Shantakumar said and alleged that the government was also apathetic towards farmers. Sugarcane growers in North Karnataka districts in general and those in Belgaum district often bear the brunt of price fluctuation as the region accounts for nearly $65 \%$ of sugarcane production. The area under sugarcane cultivation in the state is 3.5 lakh hectares and the requirement by all the factories put together is 3 crore tonnes. Farmers' leader in Bagalkot Muttappa Komar said the government should take the responsibility of not only fixing the price of sugarcane but also implement the same. The government should ensure that the factory accept the sugarcane and pay the price fixed by the government to farmers. One of the major difficulties faced by Sugar mills is their inability to appropriate storage space for the sugar produced by them. While some sugar mills have arranged temporary infrastructure to store surplus sugar however, any unfavorable weather event may result in incomprehensible damage.

Sugar mills are also now burdened with low cash inflow while the capital requirement continues to swell. This may lead to the mounting of liquidity pressures on companies which have high repayment obligations in the short to medium term and are holding excess inventory. Cane arrears (amount which sugar mills supposed to pay to farmers against the purchase of sugarcane) are also likely to swell in the current scenario. Any further extension in lockdown may put more pressure on the liquidity of the millers.

In Cash flow pressure on sugar mills will lead to the delay in payment of cane arrears to Farmers Some of the sugar mills already have accumulated cane arrears of previous years, the adverse impact caused by Covid - 19 may lead to the further accumulation. Any delay in payment of arrears to farmers will lead to the cash crunch at farmers end. There is an estimated arrear of Rs.160, 000 million. With sugar mills along with last year's accumulated arrears of Rs.8, 500 Million. The maximum dues are in Uttar Pradesh, followed by Karnataka. The mills in Maharashtra have paid $90 \%$ of their arrears.

\section{Institutional support to Farmers and Sugar Industry}

On request of Indian Sugar Mill Association (ISMA) oil marketing companies (OMCs) have agreed to relocate the ethanol in states where depots have storage capacities to accommodate the stock. This will reduce the disruptions caused in supply of ethanol and will benefit sugar mills. Sugar was declared an essential commodity. Hence, during lockdown, Government allowed harvesting, transportation and crushing operations of sugar mills. $\mathrm{n}$ Some of the development organizations like SOLIDARIDAD who are supporting farmers through extension services and training around good agriculture practices have adopted digital mediums like WhatsApp, YouTube, Conference calls and other modes to reach out to farmers and disseminate requisite information.

\section{References}

[1] Anonymous.2020. International labor Organization. Almost 25 million jobs could be lost world wide as a result of Covid 19 says ILO March 18, 2020.

[2] https: //www.ilo. org/global/about - the ilo/newsroom/news/WCMS_738742/lang-en/index. htm

Accessrd May 4, 2020

[3] http: //www.unemploymentinindia. cmie. com/. Accessed 7 May 2020

[4] Covid - 19 to put pressue on sugar industry as domestic consumption, exports to take a hit, FE Bureau, Published: April 16.2020. 